
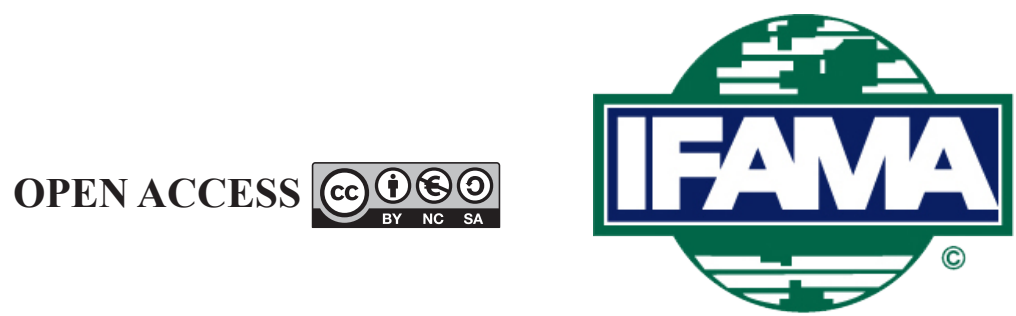

International Food and Agribusiness Management Review

Volume 25, Issue 1, 2022; DOI: 10.22434/IFAMR2020.0033

Received: 1 March 2020 / Accepted: 23 August 2020

\title{
Audit quality and the cost of debt in private firms: evidence from the Brazilian sugarcane industry \\ RESEARCH ARTICLE
}

\begin{abstract}
Aviner Augusto Silva Manoel ${ }^{\oplus a}$, Marcelo Botelho da Costa Moraes ${ }^{\mathrm{b}}$, David Ferreira Lopes Santos ${ }^{\mathrm{c}}$ and Gabriel Pereira Pündrich ${ }^{\mathrm{d}}$
\end{abstract}

${ }^{a}$ PhD in Controllership and Accounting, ${ }^{b}$ Professor of Financial Accounting, Department of Accounting,

School of Economics, Business Administration and Accounting, University of São Paulo (USP),

Av. dos Bandeirantes, 3900-FEA-RP, 14040-905 Ribeirão Preto, São Paulo, Brazil

${ }^{c}$ Assistant Professor, Department of Economy, Administration and Education, São Paulo State University (UNESP), School of Agricultural and Veterinarian Sciences, Jaboticabal. Rod. Prof. Paulo Donato Castellane, S/N, 14.884-900 Jaboticabal, São Paulo, Brazil

${ }^{d}$ Assistant Professor, University of Florida, Warrington College of Business, Gerson Hall, Gainesville, FL 32601, USA

\begin{abstract}
Evidence is mixed regarding the economic benefits achieved by companies hiring large firms to audit their financial statements. The studies approaching this theme concentrate mostly on public companies in developed markets, while the effect on private firms in emerging markets is still an open question. This research explores this gap by analyzing whether private firms in the Brazilian sugarcane industry audited by a Big 4 have a lower cost of debt than those audited by a non-Big 4. For that, a unique, hand-collected, dataset was used. This paper contributes to the literature by providing evidence of the role of audit institutions in an environment lacking studies on private firms' financial reports, especially in emerging economies. The empirical analysis does not indicate that the cost of debt is negatively influenced by the verification of financial statements by a high-quality auditor. Banks and credit unions, as the primary funding sources of the industry, condition the cost of debt reduction to the levels of tangibility, leverage, and profitability. We also contribute to the literature by demonstrating that lenders may have other soft information sources, obtained through banking relationship, which may substitute higher-quality auditor. The results hold after robustness checks and endogeneity concerns.
\end{abstract}

Keywords: agribusiness, Big 4 auditor, audit, emerging markets JEL code: M40, Q13, Q14

(i)Corresponding author: aviner@usp.br 


\section{Introduction}

When credit is granted to a borrower, capital holders need, among other things, the information available to them to be verifiable (Minnis, 2011). Minnis (2011) states that the review of financial statements by an independent organization is an essential aspect of financial reporting. This step provides guarantees that accounting information audited with greater strictness is more likely to represent the firm's economic reality, thereby reducing the probability of bias and analytical errors (Bushman and Smith, 2001).

Private firms, compared to public ones, do not have access to all funding options from the capital market. They do not have access to the stock market for external financing, and they are not allowed to issue public bonds. This imposes some limits on their investment capacity from funding arising from the credit market and self-funding (Beck et al., 2008).

The demand for external audits for private firms is mainly due to the need for debt contracting with banks and other private lenders (Kim et al., 2011). Therefore, their greater dependence on bank financing accentuates the importance of accounting information quality (Beck et al., 2008). In light of this situation, Mansi et al. (2004) and Pittman and Fortin (2004) state that the cost of debt for firms audited by the largest accounting firms is lower (Big N auditors). An external audit helps to reduce the information asymmetry between the company and the stakeholders (Minnis, 2011), to mitigate financial constraints and to lessen the problems of adverse selection and moral hazard (Jensen and Meckling, 1976).

In the absence of a wide range of alternative corporate governance mechanisms usually present in public companies, such as financial analysts' monitoring and supervision of market authorities, we expected that the external audits conducted by renowned companies play relevant roles in mitigating agency conflict and reducing the cost of debt (Choi and Wong, 2007). This situation happens because private firms cannot often use these alternative governance mechanisms and because insiders and external shareholders have a wider information asymmetry, making audits more valuable to them (Choi and Wong, 2007; Hope et al., 2012; Rodríguez and Alegría, 2012).

Studies such as Pittman and Fortin (2004) and Bharat et al. (2008) provide evidence that borrowers audited by high-quality accounting firms have more favorable conditions in the terms of their contracts, such as later due dates and more favorable collateral terms. However, the empirical evidence is concentrated on public companies whose results cannot be extrapolated to private firms, and the importance of the audit quality of accounting information arises as a research frontier (Ball and Shivakumar, 2005). Thus, our study explores the peculiarities of private firms - such as their lower capital dispersion, different audit incentives and governance structures - to analyze a possible advantage associated with Big 4 audits ${ }^{1}$ (Ball and Shivakumar, 2005; Chaney et al., 2004).

In the case of this research, different from previous studies, the efforts are concentrated within the Brazilian sugarcane industry. The specific characteristics of this industry, such as the importance of the biological assets in the agricultural activity, reflect the relevance of the study since they increase the need for working capital funding (Daly and Skaife, 2016).

Therefore, we state the following research question:

Does audit firm quality (Big 4) influence the cost of debt in private firms of the Brazilian sugarcane industry?

Specifically, we aim to answer this question by examining the influence of using higher audit quality firms (Big 4 or not) on the cost of debt. To accomplish this goal, a unique and representative dataset of financial

\footnotetext{
${ }^{1}$ We refer to the Big 4 accounting firms of Deloitte, Ernst and Young, KPMG and PwC.
} 
statements was used. The sample comprises yearly information from 1999 to 2016 of 47 plants and/or distilleries (527 firm-years observations) which represents more than $70 \%$ of the income of the industry.

Brazil provides a favorable setting in which to examine whether the audit process carried out by a Big 4 firm can reduce the information asymmetry, consequently decreasing the cost of debt for private firms in the Brazilian sugarcane industry. In December 2017, only 377 companies were active in the Brazilian Stock Exchange, while the country had more than 20 million active firms. Only $0.1 \%$ of these companies had earnings higher than US\$ 77 million or assets higher than US\$ 62 million, which the current legislation (Law 11,638/2007) determines as the compulsory requirement levels for an external audit. The low participation of large companies in the stock market highlights the importance of audit firms as instruments guaranteeing the quality of accounting information. Furthermore, Brazil has 392 audit firms accredited by the Brazilian Securities and Exchange Commission (CVM), among which the Big 4 firms are considered the most renowned by the market.

The sugarcane industry has attracted considerable public attention because this industry is a great ally of Brazil. For example, data released by the Sugarcane Industry Union (UNICA) in 2016 show that the industry is responsible for approximately 4.5 million direct and indirect jobs and generates a gross domestic product (GDP) of US\$ 40 billion, equivalent to $2 \%$ of the total Brazilian GDP (UNICA, 2016). In 2016, the industry had 347 active plants and/or distilleries in the country, which accounted for more than $25 \%$ of the sugar produced in the world. Among these firms, only three (Biosev, Raizen Energia and São Martinho) are listed on the Brazilian Stock Exchange. Therefore, these data highlight the economic, productivity, food safety, and social relevance of the financial results of the industry, especially its private companies.

Thus, given that privately held firms constitute the majority of the Brazilian economy and of the sugarcane industry itself, this article contributes to the literature by providing evidence of the role of audit institutions in an environment lacking studies on private firms' financial reports (Cassar, 2011; Rodríguez and Alegría, 2012), especially in emerging markets (Kim et al., 2011). Furthermore, no previous study in the agribusiness literature has been able to address whether the presence of a Big 4 auditor is associated with a reduction in the cost of debt. Hence, the evidence of our research provides useful insights into a hitherto under researched question.

This paper also provides practical implications for agribusiness by demonstrating that when a private firm from the Brazilian sugarcane industry hire a higher-quality auditor to audit their financial statements, it is not rewarded with a lower cost of debt, ceteris paribus. A possible interpretation of this finding it that lenders in the industry may have other 'soft' sources of information for solving the agency problems related to debt contracting. According to Cassar (2011), the other sources of information are 'soft' in the sense that it is hard to quantify and may not be verifiable by outsiders.

Then, in a further robustness test, we address the effects of the banking relationship in our findings. The new results provide support to the literature on banking relationship, thereby suggesting that the relationship between the parties via informal channels reduces information asymmetries and the cost of debt. Therefore, the 'soft' information obtained through banking relationships may provide superior information for assessing credit worthiness. This suggest that the role played by the auditor choice, at least for this study's context, demonstrated to be of second order in mitigating the agency costs and that the financial statements are not the only source of information that lenders use to assess firms' financial condition. In light of the need to learn more about audit quality in different settings, another important contribution of this research is to provide evidence about the influence of banking relationship in determining the cost of debt in the agroindustry.

The remaining of the study is organized as follows. In Section 2, the research hypothesis is developed; Section 3 is dedicated to the data and to the empirical methodology, in which the research sample is described and the methodological procedures are presented; Section 4 reports the results and a variety of robustness checks; Section 5 contains the final considerations. 


\section{Hypothesis development}

Jensen and Meckling (1976) suggest that the external audit is a corporate governance mechanism that can mitigate part of the agency problem resulting from the separation of ownership and control in firms. The demand for an external audit by private firms happens mostly because of their need to obtain external funding, especially from banks and other private lenders (Kim et al., 2011).

In this context, Ball and Shivakumar (2005) state that the demand for accounting information differs significantly between public and private companies. The demand of public firms' stakeholders for high-quality public information is greater due to the higher levels of information asymmetry, its capital dispersion (both geographically and in the number of shareholders) and the high existing agency costs (Hope et al., 2012). Conversely, the financial information of private firms is more susceptible to being influenced by factors related to taxes, dividend policies and meeting the demands of their capital providers (Ball and Shivakumar, 2005; Hope et al., 2012, 2013).

The literature also highlights that private firms are more dependent on external audits as a corporate governance mechanism due to the lack of mechanisms complementing the audit quality in reducing the agency conflicts (Rodríguez and Alegría, 2012). Additionally, public companies are still under the supervision of capital market authorities and have market measures of the company value, which offer protection to investors and can reduce the incremental value of the audit quality for public companies (Chaney et al., 2004; Rodríguez and Alegría, 2012).

Hence, in private firms, due to the unavailability or difficulty of deploying other governance mechanisms, audit quality can be one of the few formal existing mechanisms that can be used to mitigate agency costs (Hope and Vyas, 2017; Rodríguez and Alegría, 2012). Additionally, the low quality of the private firms' financial information means that these firms' interested parties face a greater risk of being deceived by earnings manipulation (Ball and Shivakumar, 2005).

In this sense, the literature document that the verifiability of the financial statements by a high-quality auditor is more important for privately held firms (Fortin and Pittman, 2007), especially because they disclose less non-accounting information and because they are more dependent on bank financing (Hope and Vyas, 2017). These facts increase the importance of accounting information for creditors in monitoring managerial activities in an attempt to reduce the information asymmetry between managers and external shareholders (Hope et al., 2012; Rodríguez and Alegría, 2012).

Moreover, the Brazilian market is still characterized by a lack of funding sources, and its interest rates are among the highest in the world (Crisóstomo et al., 2013). Thus, in a context of reduced funding sources, diminishing information asymmetry between companies and creditors is essential since information asymmetry is one of the primary causes of financial constraints and the higher costs of capital (Ascioglu et al., 2008).

The Brazilian sugarcane industry is capital intensive and has a high ownership concentration (Manoel et al., 2016), and industry members, mostly privately held, are dependent on external funding for the pursuit of their activities and even for their maintenance in a competitive market (Manoel et al., 2017, 2018). We expected, consequently, that audit quality would play a relevant role in corporate governance to reduce agency conflicts existing between principals (banks, suppliers and clients, among others) and managers as well as improve financial information quality, thus reducing the cost of debt. Therefore, this study's hypothesis is as follows:

H1: Private firms of the Brazilian sugarcane industry audited by Big 4 have, ceteris paribus, a lower cost of debt in comparison to those audited by a non-Big 4 . 
Nevertheless, not all authors point to a reduction in the cost of debt after hiring a Big 4 auditor, as shown by Kim et al. (2011) and Huguet and Gandía (2014). Kim et al. (2011), using a sample of private Korean companies, found that the appointment of a Big 4 auditor does not lead to a greater reduction in the cost of debt. In the same way, Huguet and Gandía (2014) found weak evidence that Spanish SMEs (small- and medium-sized enterprises) audited by a Big 4 auditor have a lower cost of debt than SMEs audited by nonBig 4 auditors. That situation happens, according to Kim et al. (2011), due to the relevant role played by the relationship built over the years between banks and private firms in debt contracting and by the greater importance given by lenders to the presence of external audits (audit versus no audit) instead of on audit quality (Big 4 versus non-Big 4).

The relationship banking literature suggests that the closer relationship between privately held firms and banks or other private lenders facilitates an informal additional information flow between the two parties via direct communication channels. Thus, the advantage in obtaining private information and the superior ability to collect and process this information can be useful in mitigating the problems of adverse selection and moral hazard (Diamond, 1991; Petersen and Rajan, 1994).

This closer relationship represents an important information source that can reduce information asymmetry and agency conflicts, thus also reducing the cost of debt for private firms (Diamond, 1991). The above arguments suggest that direct communication via informal channels may be more relevant than indirect communication through financial statements audited by a Big 4 firm and that financial statements are a supplemental information source (Berger and Udell, 1995; Kim et al., 2011). Hence, a possible nonsignificant statistic in the relationship between the cost of debt and the audit quality can also be a likely outcome of this study.

\section{Research design}

\subsection{Research sample}

The annual financial statements of private plants and distilleries in the Brazilian sugarcane industry were used in this study. Nominal data ${ }^{2}$ were hand-collected from the Official Journal of the Brazilian Government. The sample organizations were chosen according to their data availability throughout the analyzed period (1999-2016) and the existence of information related to the company conducting the external audit in each respective financial year.

In 2016, the Brazilian sugarcane industry consisted of approximately 347 mills and distilleries. Among the firms, only 47 presented all the required data. However, the sample represents more than $70 \%$ of the income of the industry, illustrating its relevance. Therefore, the final sample of this study is composed of 47 companies, which results in unbalanced panel data with 524 observations for the period from 1999 to 2016.

\subsection{Variable description}

\section{- Dependent variable}

The interest rates of the firms were not directly reported in the financial statements collected in this study. Thus, the cost of debt was estimated based on the studies of Pittman and Fortin (2004), Minnis (2011) and Daly and Skaife (2016), in which it was obtained by dividing the reported interest expenditures by the average of short- and long-term debt [(short-term debt + long-term debt) / 2].

\footnotetext{
${ }^{2}$ Unreported results indicate that our main findings are robust, regardless of whether the variables were updated by an inflation index (National Extended Consumer Price Index) or not.
} 
Minnis (2011) recognizes that an estimated average cost of debt measure results in substantial noise in the dependent variable. This phenomenon occurs, first, because the inferred cost of debt measure suffers from staleness since a portion of the observed interest rate has been contracted from previous years. Second, the identification and measurement of liabilities, particularly debt contracted at arm's length, is less evident in smaller firms versus public ones.

These problems in the identification of total liabilities (denominator) and interest expenses (numerator) can generate considerable noise in the estimation of the cost of debt (Cassar, 2011). To mitigate part of the problem in estimating the cost of debt, Pittman and Fortin (2004) and Minnis (2011) suggest truncating the dependent variable at the $5^{\text {th }}$ and $95^{\text {th }}$ percentiles. Consequently, this procedure was also performed in this study to estimate the cost of debt ${ }^{3}$.

\section{- $\operatorname{Big} 4$}

The quality of an audit is not public information and cannot be directly observed by financial statement users. Therefore, De Angelo (1981) state that financial report users assume that audit quality is based on the auditor's reputation. The greatest audits (Big N), which are addressed in the literature as the Big Four (Deloitte, KPMG, PwC, and Ernst and Young) have a greater reputational risk and are under less pressure to succumb to an individual client.

When compared to other auditors, the Big 4 firms have more expertise, more competence, a greater number of experts, more robust training programs, and standardized audit methodologies, and they are better equipped to continuously update their technologies and processes (Chaney et al., 2004; Hope et al., 2013). This evidence suggests that the Big 4 firms provide high-quality audits (Becker et al., 1998; DeAngelo, 1981). Hence, a binary variable was used in this study to capture the effect of the audit quality construct. The variable was assigned a value of 1 if the firm was audited in each fiscal year by a Big 4 firm and 0 otherwise.

\section{- Control variables}

Eight control variables were also inserted in the proposed econometric model, according to the evidence obtained in the literature, with the aim of isolating the effects of a firm being audited by a Big 4 firm and its respective impact on the cost of debt. To avoid the possible effects of outliers on the results, the continuous variables were winsorized at their $1^{\text {st }}$ and $99^{\text {th }}$ percentiles.

Tangibility: tangible assets - such as property, plant and equipment (PPE) - are less liquid and more easily identified. These characteristics reduce the manager's capacity to expropriate these resources improperly (Minnis, 2011) when compared to cash (Manoel et al., 2017). In this respect, Minnis (2011) states that firms with more tangible assets may receive fewer benefits from external monitoring due to a lack of liquidity and the collateral value of their assets. On the other hand, firms with larger PPE have more guarantees on loans, and their informational asymmetry is lower, which suggests a negative relationship with the cost of debt.

Current liquidity: the current liquidity variable, which is obtained by dividing current assets by current liabilities, was also included in our model. Companies with a low ratio of current liquidity may suffer from problems related to financial distress, and they may be forced to use more expensive forms of credit. Hence, we expect a negative relationship of current liquidity on the cost of debt (Rodríguez and Alegría, 2012).

Profitability: a variable of profitability was also included as a control. Banks and other private lenders are more likely to charge lower interest rates of more profitable organizations because they are better able to

\footnotetext{
${ }^{3}$ We mention, however, that unreported results show that the extreme values do not influence our evidence, since we find similar results when we did not truncate the dependent variable.
} 
service their debt. In this article, we use return on assets (ROA), obtained by dividing net income by total assets (Kim et al., 2011), as the best measure available for firm performance.

Size: to control for firm size, the natural logarithm of total assets was used, according to Bharath et al. (2008) and Kim et al. (2011). The theoretical justification for its use is that larger firms have better reputations in the debt market, suggesting a negative relationship with the cost of debt (Diamond, 1989).

Growth opportunities: firms with more investment opportunities have a greater demand for quality financial statements to ease their access to funding sources (Hope et al., 2012; Minnis, 2011). Thus, a positive association between growth opportunities, measured as the yearly growth rate of a firm's sales (Ball and Shivakumar, 2005) and cost of debt, is expected.

Leverage: a positive association between leverage, which is obtained by the ratio of total debt to total assets, and agency conflicts with the debt market is expected. This phenomenon occurs since the agents of firms with less equity have more incentives to engage in asset substitution (Jensen and Meckling, 1976). Notwithstanding, auditors may still interpret firms with greater leverage as being greater bankruptcy risks (Kim et al., 2011).

Age: older companies are usually characterized by a lower degree of information asymmetry and a lower cost of debt than younger firms (Lyandres, 2007). For this reason, we also included the age variable in our model, which is measured by the natural logarithm of the firm's age.

Negative equity: finally, the binary variable negative equity was also included. The variable was assigned a value of 1 for those firm-year observations reporting negative equity, and it is 0 otherwise. Firms with negative equity are expected to face greater financial distress, causing lenders to demand a higher cost of debt due to the risk (Kim et al., 2011).

\subsection{Econometric model}

Regarding the econometric model, the panel data regression model with an unbalanced panel was chosen. Among the possible choices of the ordinary least squares (OLS), fixed effects and random effects models, the fixed effects model was chosen.

This decision was made because studies about audit choice are subject to endogeneity problems since the choice of whether to use a Big 4 auditor is not random but is a corporate decision based on the company's characteristics, private information and other non-observable characteristics (Chaney et al., 2004). Clatworthy et al. (2009), Kim et al. (2011) and Lennox et al. (2012) state that the estimates of the OLS are not the best due to the self-selection bias and omitted variables problems.

To mitigate part of these problems, the studies of Mansi et al. (2004) and Pittman and Fortin (2004) suggest the use of the Heckman two-stage approach. However, evidence from Clatworthy et al. (2009) and Lennox et al. (2012) indicates that, although this approach represents an innovative correction for self-selection bias, the Heckman estimator depends on a proper selection of the instrumental variables, which are extremely difficult to obtain in practice. Furthermore, the Heckman model is sensitive to model specification, collinearity and sample composition. Hence, if the Heckman estimator is not properly identified, then more biased and unreliable results may occur than in the OLS estimation due to severe collinearity problems (Clatworthy et al., 2009; Lennox et al., 2012).

Kim et al. (2011) and Lennox et al. (2012) suggest that fixed effects regression allows one to mitigate part of the potential problems of correlated omitted variables by controlling for unobservable, time-invariant, firmspecific characteristics. Therefore, the fixed effects model was chosen to partially mitigate the endogeneity 
problems and to control the non-observable and specific characteristics of each company. The theoretical model proposed in this study is as follows:

$$
\begin{aligned}
K i_{i, t}= & \beta_{i}+\beta_{1} \text { BIG }_{i, t}+\beta_{2} \text { Tangibility }_{i, t}+\beta_{3} \text { Current Liquidity }_{i, t}+\beta_{4} \text { ROA }_{i, t}+\beta_{5} \text { Size }_{i, t}+ \\
& \beta_{6} \text { Growth Opportunities }_{i, t}+\beta_{7} \text { Leverage }_{i, t}+\beta_{8} \text { Age }_{i, t}+\beta_{9} \text { Negative Equity }_{i, t}+\varepsilon_{i, t}
\end{aligned}
$$

$\mathrm{Ki}=$ cost of debt, which is obtained by dividing the reported interest expenditures by the average of total debt; BIG4 = binary variable taking the value 1 if the organization is audited by a Big 4 firm (Deloitte, Ernst and Young, KPMG or PWC) in each respective financial year and 0 otherwise; Tangibility = defined as the relationship of tangible assets (PPE) to total assets; Current Liquidity = obtained by dividing the current assets by the current liabilities; ROA = return on assets, which is obtained by dividing the net income by total assets; Size $=$ obtained via the natural logarithm of the total assets; Growth Opportunities $=$ the year-over-year percentage growth in revenues; Leverage $=$ obtained by the ratio of total debt to total assets; Age $=$ obtained by the natural logarithm of the age of the firm; Negative Equity = a binary variable taking the value 1 if the company has negative equity in the respective financial year and 0 otherwise; and $\varepsilon=$ classic error term.

\subsection{Descriptive statistics}

Table 1 presents the descriptive statistics of 47 companies from the Brazilian sugarcane industry throughout the 1999-2016 period. Of the observations, 63.36\% (36.64\%) were audited by a Big 4 firm (non-Big 4 firm). Considering that 392 audit firms are registered at the Comissão de Valores Mobiliários (CVM) in Brazil, which is the Brazilian securities regulator, as of December 2017, this information highlights the views on and the market share concentrations of the Big 4 companies in the Brazilian market.

In addition, the average cost of debt was $26.8 \%$, and the average age of firms was approximately 42.12 years. The descriptive statistics also indicate that, on average, the plants and distilleries of the industry maintained $48 \%$ of their total assets as tangible assets. This number was expected because the industry is capital intensive

Table 1. Descriptive statistics of the variables. ${ }^{1}$

\begin{tabular}{llllll}
\hline Variable & Mean & Std. Dev. & Q1 & Median & Q3 \\
\hline Cost of debt (Ki) & 0.268 & 0.206 & 0.129 & 0.193 & 0.346 \\
BIG 4 & 0.634 & 0.482 & 0.000 & 1.000 & 1.000 \\
Tangibility & 0.480 & 0.178 & 0.354 & 0.500 & 0.616 \\
Current liquidity & 1.432 & 1.267 & 0.631 & 1.074 & 1.764 \\
ROA & 0.038 & 0.091 & -0.015 & 0.046 & 0.091 \\
Size (thousands of reais-BRL) & $610,678.32$ & $697,423.41$ & $155,361.25$ & $372,194.50$ & $785,866.00$ \\
Growth opportunities & 0.214 & 0.441 & 0.013 & 0.161 & 0.332 \\
Leverage & 0.367 & 0.202 & 0.223 & 0.345 & 0.490 \\
Age & 42.120 & 23.589 & 24.000 & 40.000 & 58.000 \\
Negative equity & 0.090 & 0.286 & 0.000 & 0.000 & 0.000 \\
\hline
\end{tabular}

${ }^{1}$ Cost of debt (Ki) is the dependent variable of this study, it was obtained by dividing the reported interest expenditures by the average of the total short-term and long-term debt during the year; Big 4 is a binary variable that takes the value 1 if the organization is audited by a Big 4 firm (Deloitte, Ernest Young, KPMG or PwC) in each respective financial year and 0 otherwise; Tangibility is defined as the relationship of tangible assets (property, plant and equipment) to total assets; Current liquidity was obtained by dividing the current assets by the current liabilities; Return on assets (ROA) was obtained by dividing the operating profit by total assets; Size is the sum of total assets in thousands of reais-BRL; Growth opportunities is the year-over-year percentage growth in revenues; Leverage was obtained by the sum of short-term and long-term total debts divided by the total assets; Age was obtained by the natural logarithm of the age of the firm; Negative equity is a binary variable that takes the value 1 if the company has negative equity in the respective financial year, and 0 otherwise; Year dummies are included in Models 1 and 2; Std. Dev. = standard deviation; we used fixed effects regressions in all the models. 
and large investments are required in machinery, plants and land. The variable of profitability used, measured by the ROA, presents an average value of 3.8\%. Moreover, the companies of the industry presented a growth in sales of approximately $21.4 \%$ and an average indebtedness level of $36.7 \%$. The mean firms have assets of R $\$ 610,678.32$ (thousands of reais-BRL). Finally, 9\% of the companies presented negative equity.

\section{Results and discussion}

Supplementary Table S1 reports the correlation matrix and the variance inflation factor (VIF) of the variables used in the model. This table shows that multicollinearity is not a problem in this study since the highest VIF was 1.58 for leverage. The result of the White test (with a $P$-value of 0.000 ) for heteroskedasticity shows that the sample presented a great dispersion around the straight line. Thus, to mitigate residual heteroskedasticity and serial correlation concerns, we used robust standard error because of its better adjustment for samples with heteroskedasticity problems. Table 2 presents the results obtained via the fixed effects model with the inclusion of the robust standard error.

The results in Table 2 show the lack of statistical significance for the proxy of the audit quality construct used in this study. Therefore, our findings do not indicate that the cost of debt falls significantly when a Big 4 firm audits a firm from the Brazilian sugarcane industry. This result illustrates that privately held firms from the industry that choose to be audited by a Big 4 auditor are not rewarded with a lower cost of debt. It is important to note, however, that the lack of significance may be due to the limited sample size.

Table 2. Fixed effects regression models with robust standard errors. ${ }^{1,2}$

\begin{tabular}{lcl}
\hline Variables & Coefficients & $\boldsymbol{P}$-value \\
\hline Constant & 0.751 & $0.001^{* * *}$ \\
BIG 4 & -0.053 & 0.495 \\
Tangibility & -0.201 & $0.007^{* * *}$ \\
Current liquidity & 0.001 & 0.967 \\
ROA & -0.411 & $0.002^{* * *}$ \\
Size & -0.011 & 0.619 \\
Growth opportunities & 0.031 & $0.051^{*}$ \\
Leverage & -0.557 & $0.000^{* * *}$ \\
Age & -0.002 & 0.966 \\
Negative equity & 0.078 & $0.068^{*}$ \\
$P$-value $(F) 0.000$ & & \\
Durbin-Watson $=1.242$ & & \\
$\mathrm{R}^{2}=28.94 \%$ & & \\
Observations $(\mathrm{n})=524$ & & \\
\hline
\end{tabular}

$1 *$ statistically significant at $10 \% ; * * *$ statistically significant at $1 \%$.

${ }^{2}$ Cost of debt (Ki) is the dependent variable of this study, it was obtained by dividing the reported interest expenditures by the average of the total short-term and long-term debt during the year; Big 4 is a binary variable that takes the value 1 if the organization is audited by a Big 4 firm (Deloitte, Ernest Young, KPMG or PwC) in each respective financial year and 0 otherwise; Tangibility is defined as the relationship of tangible assets (property, plant and equipment) to total assets; Current liquidity was obtained by dividing the current assets by the current liabilities; Return on assets (ROA) was obtained by dividing the operating profit by total assets; Size was obtained via the natural logarithm of the total assets; Growth opportunities is the year-over-year percentage growth in revenues; Leverage was obtained by the sum of short-term and long-term total debts divided by the total assets; Age was obtained by the natural logarithm of the age of the firm; Negative equity is a binary variable that takes the value 1 if the company has negative equity in the respective financial year, and 0 otherwise; Year dummies are included in Models 1 and 2; We used fixed effects regressions in all the models. 
The literature on banking relationships points out that relationship banking information may be a better source of information about private firms' worthiness than 'hard' quantitative information, such as accounting reports or credit scores (Cassar, 2011). Banks and other private lenders, as the main capital suppliers of private firms, have better abilities to collect and process borrowers' private information via communication channels, which are used to designate contract terms to discipline the borrower's investment decisions and to protect lenders in case of default (Berger and Udell, 1995).

Access to private information reduces the costs of adverse selection faced by borrowers with low-quality financial statements and ex post monitoring costs (Bharath et al., 2008; Kim et al., 2011). This reduction reduces the demand for information provided by financial reports (Bharath et al., 2008). Therefore, banks and other private lenders can overcome problems related to the low quality of financial statements via private communication channels. According to Kim et al. (2011), this situation suggests that the role played by high-quality audits is of second order in the mitigation of agency problems when contracting debt.

A possible interpretation of our empirical analysis is that banks and credit unions, as the primary funding sources of the industry, may have other sources of information to solve agency conflicts. Among these other sources of information, the literature notes (Diamond, 1991; Petersen and Rajan, 1994) the relevance played by relationship banking. As a result, lenders did not condition a reduction in the cost of debt on the selection of a Big 4 auditor in the Brazilian sugarcane industry.

Furthermore, since Brazil's debt-recovery legislation and the fiscalization of corporate and fiscal information by regulatory agencies are fragile, the results might suggest that creditors value the relationship and knowledge of the financial conditions of borrowers over the quality of the financial statements. In this sense, tangibility has a negative and significant relationship with the cost of debt since firms with larger PPE offer greater protection to creditors (Minnis, 2011) and can be used to generate cash holdings when facing financial constraints.

The inverse relationship between ROA and the dependent variable corroborates this result since companies with higher levels of profitability offer lower risk levels to banks; then, a lower cost of debt is required. Higher levels of profitability are generally expressed by greater cash flows since this information is known and accompanied by the banks' credit score systems. The negative and significant relationship between leverage and the cost of debt ratifies our findings that choosing a Big 4 auditor does not lead to a lower cost of debt.

The median leverage of the Brazilian sugarcane industry is less than $1 / 3$ of its assets, and the $3^{\text {rd }}$ quartile is less than 50\%. Thus, companies with the highest leverage are not 'highly' leveraged companies. Therefore, firms in this industry use third-party sources as a financial strategy for making feasible investments, and the positive track records with financial institutions as well as close relationships tend to reduce financing costs. The positive and significant relationship of the negative equity dummy with the cost of debt also corroborates this analysis. Thus, firms with negative equity present higher levels of risk to banks; consequently, higher interest rates are required of them.

The Brazilian sugarcane industry is intensively vested in tangible assets, given that the industry maintains $48 \%$ of its total assets in PPE. The inherent subjectivity in intangible assets, which are non-monetary assets that lacks physical substance (like computer software, copyrights and patents), makes this asset objectively difficult to verify and valuate in comparison to tangible assets (DeFond and Zhang, 2014). In addition, Defond and Zhang (2014) further state that financial reporting quality should be lower for firms with innate characteristics that are difficult to measure.

Consequently, the degree of informational asymmetry in the industry is less pronounced than that in companies who invest most of their structure in intangible assets and whose assets consist primarily of investment opportunities. Hence, ceteris paribus, financial reporting quality is expected to be higher in the industry, possibly leading to the less pronounced importance of being audited by a Big 4 firm. Given all of the above, 
we cannot conclude that the cost of debt in the industry is negatively influenced by the verification of the financial statements by a high-quality auditor since the empirical analysis did not show a reduction in the cost of debt for the firms audited by a Big 4 firm.

Regarding the control variables, as previously discussed, the signs of each of the coefficients are in accordance with the theoretical assumptions, except for leverage, which is due to the obtaining of a negative and significant coefficient at the $1 \%$ level. This result could indicate that companies that are subject to lower cost of debt have higher borrowing capacities or loan incentives than other firms that have to pay higher interest rates. This reverse causality could explain the counter intuitive result for leverage, that is, the higher the leverage in the industry the lower the cost of debt (Piot and Missonier-Piera, 2007). In addition, to a given point, increases in leverage leads to a reduction in the interest rate, as a result of better financing condition. However, from a certain level, this association becomes positive due to the greater risk of bankruptcy (Huguet and Gandía, 2014). We mention, however, that the positive association between leverage and the cost of debt should be interpreted with caution, since the sign of the coefficient only reflects an association instead of causality (Piot and Missonier-Piera, 2007).

With respect to the estimated coefficients of the other control variables, the following was verified. First, banks and other private lenders charge lower interest rates to firms in the Brazilian sugarcane industry with higher asset tangibility. Second, the most profitable companies pay, on average, a lower cost of debt. Third, organizations with greater investment opportunities and firms with negative equity pay, on average, a higher cost of borrowing in terms of interest. Finally, the current liquidity, size and age variables did not obtain statistical significance.

\subsection{Robustness tests}

To give additional support to the results obtained, we performed some robustness tests. First, year dummies were included to control for the unobserved and time-specific effects common to all organizations. The results in the second column (Model 1) of Table 3 suggest that the inclusion of year dummies produces qualitatively similar inferences on the variables.

Moreover, the cost of debt paid by firms is not directly observable. As a result, the cost of debt was estimated based on the studies of Pittman and Fortin (2004), Minnis (2011) and Daly and Skaife (2016), in which the estimate was obtained by dividing the interest expenditures reported by the average of short- and longterm debt. However, despite its wide use in the literature, this measure is a noisy proxy for the interest rate in private companies, and Cassar (2011) identifies several limitations of this proxy, such as the fact that it considers the average level of debt instead of the loan characteristics and does not identify which liabilities are at arms' length.

Huguet and Gandía (2014) suggest that part of these limitations can be reduced by including the lagged dependent variable as a control, given that this variable can control the portion of the interest rate due to prior years. Thus, the third column (Model 2) of Table 3 includes the dependent variable lagged with year dummies, and the fourth column (Model 3) includes only the lag of the dependent variable without the use of year dummies. The obtained results were very similar to the previous ones, despite the increase in the explanatory power $\left(\mathrm{R}^{2}\right)$ of the results and the fact that age became positive and statistically significant.

In addition, we examine two interactions to determine whether the presence of a Big 4 auditor is more important in reducing the cost of debt of privately held firms with higher leverage and of larger size. In this sense, two interaction variables (Size_Big 4 and Leverage_Big 4) were added to the initial econometric model. The results reported in the fifth column (Model 4) of Table 3 showed that only Leverage_Big 4 was significant with a positive sign at the $5 \%$ level. The coefficients of the other variables were consistent with those in Table 2. 
Table 3. Regression results of the robustness checks. ${ }^{1,2}$

\begin{tabular}{|c|c|c|c|c|c|c|c|}
\hline & Model 1 & Model 2 & Model 3 & Model 4 & Model 5 & Model 6 & Model 7 \\
\hline & $\begin{array}{l}\text { Coefficients } \\
\text { (P-value) }\end{array}$ & $\begin{array}{l}\text { Coefficients } \\
\text { (P-value) }\end{array}$ & $\begin{array}{l}\text { Coefficients } \\
\text { (P-value) }\end{array}$ & $\begin{array}{l}\text { Coefficients } \\
\text { (P-value) }\end{array}$ & $\begin{array}{l}\text { Coefficients } \\
\text { (P-value) }\end{array}$ & $\begin{array}{l}\text { Coefficients } \\
\text { (P-value) }\end{array}$ & $\begin{array}{l}\text { Coefficients } \\
\text { (P-value) }\end{array}$ \\
\hline Constant & $\begin{array}{l}0.312 \\
(0.5122)\end{array}$ & $\begin{array}{l}-0.321 \\
(0.398)\end{array}$ & $\begin{array}{l}0.149 \\
(0.311)\end{array}$ & $\begin{array}{l}0.861 \\
(0.000 * * *)\end{array}$ & $\begin{array}{l}0.768 \\
(0.000 * * *)\end{array}$ & $\begin{array}{l}0.742 \\
(0.000 * * *)\end{array}$ & $\begin{array}{l}0.000 \\
(0.881)\end{array}$ \\
\hline $\mathrm{Ki}_{\mathrm{t}-1}$ & - & $\begin{array}{l}0.319 \\
(0.000 * * *)\end{array}$ & $\begin{array}{l}0.308 \\
(0.000 * * *)\end{array}$ & - & - & - & $\begin{array}{l}0.298 \\
(0.000 * * *)\end{array}$ \\
\hline BIG 4 & $\begin{array}{l}-0.041 \\
(0.593)\end{array}$ & $\begin{array}{l}-0.021 \\
(0.720)\end{array}$ & $\begin{array}{c}-0.023 \\
(0.699)\end{array}$ & $\begin{array}{c}-0.141 \\
(0.102)\end{array}$ & $\begin{array}{c}-0.051 \\
(0.509)\end{array}$ & $\begin{array}{l}-0.050 \\
(0.524)\end{array}$ & $\begin{array}{l}-0.079 \\
(0.139)\end{array}$ \\
\hline Tangibility & $\begin{array}{l}-0.164 \\
(0.0312 * *)\end{array}$ & $\begin{array}{l}-0.207 \\
(0.006 * * *)\end{array}$ & $\begin{array}{l}-0.223 \\
(0.000 * * *)\end{array}$ & $\begin{array}{l}-0.158 \\
(0.031 * *)\end{array}$ & $\begin{array}{l}-0.175 \\
(0.099 * * *)\end{array}$ & $\begin{array}{l}-0.233 \\
(0.000 * * *)\end{array}$ & $\begin{array}{l}-0.397 \\
(0.000 * * *)\end{array}$ \\
\hline Current liquidity & $\begin{array}{l}0.009 \\
(0.6451)\end{array}$ & $\begin{array}{l}0.008 \\
(0.508)\end{array}$ & $\begin{array}{l}0.003 \\
(0.778)\end{array}$ & $\begin{array}{l}-0.002 \\
(0.877)\end{array}$ & $\begin{array}{l}0.004 \\
(0.772)\end{array}$ & $\begin{array}{l}-0.007 \\
(0.697)\end{array}$ & $\begin{array}{l}-0.003 \\
(0.711)\end{array}$ \\
\hline ROA & $\begin{array}{l}-0.326 \\
(0.0144 * *)\end{array}$ & $\begin{array}{l}-0.381 \\
(0.008 * * *)\end{array}$ & $\begin{array}{l}-0.389 \\
(0.004 * * *)\end{array}$ & $\begin{array}{l}-0.396 \\
(0.003 * * *)\end{array}$ & $\begin{array}{l}-0.397 \\
(0.003 * * *)\end{array}$ & $\begin{array}{l}-0.388 \\
(0.004 * * *)\end{array}$ & $\begin{array}{l}-0.348 \\
(0.003 * * *)\end{array}$ \\
\hline Size & $\begin{array}{l}0.029 \\
(0.456)\end{array}$ & $\begin{array}{l}0.023 \\
(0.349)\end{array}$ & $\begin{array}{l}0.002 \\
(0.847)\end{array}$ & $\begin{array}{l}-0.020 \\
(0.304)\end{array}$ & $\begin{array}{l}-0.011 \\
(0.595)\end{array}$ & $\begin{array}{l}-0.013 \\
(0.553)\end{array}$ & $\begin{array}{l}0.012 \\
(0.714)\end{array}$ \\
\hline Growth opportunities & $\begin{array}{l}0.034 \\
(0.0357 * *)\end{array}$ & $\begin{array}{l}0.049 \\
(0.0088 * * *)\end{array}$ & $\begin{array}{l}0.050 \\
(0.003 * * *)\end{array}$ & $\begin{array}{l}0.033 \\
(0.027 * *)\end{array}$ & $\begin{array}{l}0.013 \\
(0.190)\end{array}$ & $\begin{array}{l}0.023 \\
(0.107)\end{array}$ & $\begin{array}{l}0.066 \\
(0.000 * * *)\end{array}$ \\
\hline Leverage & $\begin{array}{l}-0.577 \\
(0.000 * * *)\end{array}$ & $\begin{array}{l}-0.450 \\
(0.000 * * *)\end{array}$ & $\begin{array}{l}-0.446 \\
(0.000 * * *)\end{array}$ & $\begin{array}{l}-0.749 \\
(0.000 * * *)\end{array}$ & $\begin{array}{l}-0.547 \\
(0.000 * * *)\end{array}$ & $\begin{array}{l}-0.632 \\
(0.000 * * *)\end{array}$ & $\begin{array}{l}-0.436 \\
(0.000 * * *)\end{array}$ \\
\hline Age & $\begin{array}{l}0.012 \\
(0.8236)\end{array}$ & $\begin{array}{l}0.110 \\
\left(0.000^{* * *}\right)\end{array}$ & $\begin{array}{l}0.075 \\
(0.011 * *)\end{array}$ & $\begin{array}{l}0.010 \\
(0.828)\end{array}$ & $\begin{array}{l}-0.010 \\
(0.831)\end{array}$ & $\begin{array}{l}0.018 \\
(0.736)\end{array}$ & $\begin{array}{l}-0.003 \\
(0.964)\end{array}$ \\
\hline Negative equity & $\begin{array}{l}0.085 \\
(0.0407 * *)\end{array}$ & $\begin{array}{l}0.070 \\
\left(0.0256^{* *}\right)\end{array}$ & $\begin{array}{l}0.075 \\
(0.011 * *)\end{array}$ & $\begin{array}{l}0.071 \\
(0.043 * *)\end{array}$ & $\begin{array}{l}0.081 \\
(0.062 *)\end{array}$ & $\begin{array}{l}0.122 \\
\left(0.006^{* * *}\right)\end{array}$ & $\begin{array}{l}0.051 \\
(0.169)\end{array}$ \\
\hline Size*BIG 4 & - & - & - & $\begin{array}{l}0.021 \\
(0.513)\end{array}$ & - & - & - \\
\hline Leverage*BIG 4 & - & - & - & $\begin{array}{l}0.335 \\
(0.025 * *)\end{array}$ & - & - & - \\
\hline Year Dummies & Yes & Yes & No & No & No & No & No \\
\hline$P$-value (F) & 0.000 & 0.000 & 0.000 & 0.000 & 0.000 & 0.000 & 0.000 \\
\hline Durbin-Watson & 1.242 & 1.900 & 1.908 & 1.260 & 1.242 & 1.216 & - \\
\hline $\mathrm{R}^{2}$ & $33.65 \%$ & $41.88 \%$ & $38.27 \%$ & $31.05 \%$ & $28.60 \%$ & $34.12 \%$ & - \\
\hline Corr $(y, y)$ & - & - & - & - & - & - & $32.36 \%$ \\
\hline Sargan test (df) & - & - & - & - & - & - & $\begin{array}{l}155.573 \\
(135) \\
P \text {-value } \\
(0.000)\end{array}$ \\
\hline Observations (n) & 524 & 524 & 524 & 524 & 524 & 524 & 419 \\
\hline
\end{tabular}

$1 *, * *, * * *$, statistically significant at 10,5 and $1 \%$, respectively.

${ }^{2}$ Cost of debt (Ki) is the dependent variable of this study, it was obtained by dividing the reported interest expenditures by the average of the total short-term and long-term debt during the year; The cost of debt in column 6 was the only different, in which it was estimated by dividing financial expenses by liabilities; Big 4 is a binary variable that takes the value 1 if the organization is audited by a Big 4 firm (Deloitte, Ernest Young, KPMG or $\mathrm{PwC}$ ) in each respective financial year and 0 otherwise; Tangibility is defined as the relationship of tangible assets (property, plant and equipment) to total assets; Current liquidity was obtained by dividing the current assets by the current liabilities; Return on assets (ROA) was obtained by dividing the operating profit by total assets; Size was obtained via the natural logarithm of the total assets; Growth opportunities is the year-overyear percentage growth in revenues; Leverage was obtained by the sum of short-term and long-term total debts divided by the total assets; Age was obtained by the natural logarithm of the age of the firm; Negative equity is a binary variable that takes the value 1 if the company has negative equity in the respective financial year, and 0 otherwise; Year dummies are included in Models 1 and 2; We used fixed effects regressions in all the models, except on Model 7, in which we used the generalized method of moments (GMM).

International Food and Agribusiness Management Review 
The results reported in column six (Model 5) of Table 3 indicate that our regression results are robust regardless of whether the extreme observations of the continuous variables are winsorized. Our results are also robust (Model 6) to the use of an alternative measure of the interest rate, as suggested by Brazilian literature (Assaf Neto, 2014) in which the cost of debt was estimated by dividing financial expenses by liabilities.

Furthermore, to increase the robustness of our results to endogenous relations, we apply the generalized method of moments (GMM) approach by Arellano and Bond (1991) with dynamic panel data for estimation. According to Rodríguez and Alegría (2012), this estimation method produces unbiased estimates of the coefficients of the model in the presence of unobserved heterogeneity and potential endogeneity of the variables. Our results, reported in column eight (Model 7) of Table 3, are qualitatively similar to those obtained in Table 2 , even though the variable negative equity becomes nonsignificant. The results of the Sargan test indicate that the instrument variable $\left(\mathrm{Ki}_{\mathrm{t}-1}\right)$ does not correlate with the error term.

Finally, to address the effects of the banking relationship in our results, we used a subsample of firms with the percentage of debts from banks and credit unions available. Based on Bigus and Hillebrand (2017), we measured relationship lending using the ratio of bank debt to total debt. High bank debt ratios tend to indicate a relationship. Table 4 reports the new findings using the fixed effects model with robust standard errors.

As observed from Table 4, the results indicate a negative and significant relationship between the ratio of bank debt to total debt and the cost of debt. The other variables exhibit similar results to those reported in Table 3. Banks have superior information-gathering and processing abilities to assess the credibility of financial reports and the credit worthiness of a borrower (Berger and Udell, 1995; Diamond, 1991; Kim et al., 2011; Petersen and Rajan, 1994). Therefore, our evidence provides support that the relationship between banks

Table 4. Fixed effects regression models with robust standard errors. ${ }^{1,2}$

\begin{tabular}{|c|c|c|}
\hline Variables & Coefficients & $P$-value \\
\hline Constant & 0.806 & $0.002 * * *$ \\
\hline BIG 4 & -0.111 & 0.137 \\
\hline Tangibility & -0.277 & $0.000 * * *$ \\
\hline Current liquidity & 0.011 & 0.621 \\
\hline ROA & -0.462 & $0.002 * * *$ \\
\hline Size & -0.005 & 0.815 \\
\hline Growth opportunities & 0.035 & $0.043 * *$ \\
\hline Bank debt & -0.106 & $0.079 *$ \\
\hline Leverage & -0.536 & $0.000 * * *$ \\
\hline Age & 0.004 & 0.931 \\
\hline Negative equity & 0.089 & $0.067 *$ \\
\hline \multicolumn{3}{|l|}{$P$-value $(F) 0.000$} \\
\hline \multicolumn{3}{|l|}{ Durbin-Watson $=1.204$} \\
\hline \multicolumn{3}{|c|}{ Adjusted R-squared $=32.04 \%$} \\
\hline \multicolumn{3}{|c|}{ Observations $(\mathrm{n})=405$} \\
\hline \multicolumn{3}{|c|}{$1 *, * *, * * *$, statistically significant at 10,5 and $1 \%$, respectively. } \\
\hline \multicolumn{3}{|c|}{$\begin{array}{l}{ }^{2} \text { Cost of debt (KI) is the dependent variable of this study, it was obtained by dividing the reported interest expenditures by the } \\
\text { average of the total short-term and long-term debt during the year; Big } 4 \text { is a binary variable that takes the value } 1 \text { if the organization } \\
\text { is audited by a Big } 4 \text { firm (Deloitte, Ernest Young, KPMG or PWC) in each respective financial year and } 0 \text { otherwise; Tangibility } \\
\text { is defined as the relationship of tangible assets (property, plant and equipment) to total assets; Current liquidity was obtained by } \\
\text { dividing the current assets by the current liabilities; Return on assets (ROA) was obtained by dividing the net income by total assets; } \\
\text { Size was obtained via the natural logarithm of the total assets; Growth opportunities is the year-over-year percentage growth in } \\
\text { revenues; Bank debt was measured by the ratio of bank debt to total debt; Leverage was obtained by the ratio of total debt to total } \\
\text { assets; Age was measured as the natural logarithm of firm age since its foundation; Negative equity is a binary variable that takes } \\
\text { the value } 1 \text { if the company has negative equity in the respective financial year, and } 0 \text { otherwise. }\end{array}$} \\
\hline
\end{tabular}


and private firms in debt contracting plays a key role since the cost of debt is negatively associate with the ratio of bank debt. After controlling for the banking relationship, our results are robust, showing that the cost of debt is not statistically significantly lower in companies audited by a Big 4 firm.

In addition, unreported results indicate that banks and credit unions ${ }^{4}$ are the dominant source of external finance in the industry, representing $83.72 \%$ of the loans in this subsample. These findings support the fact that lenders are in a better position to gain inside information, thus suggesting that relationship banking information may be a better source of information that can reduce information asymmetry and the cost of debt for private firms in the Brazilian sugarcane industry.

\section{Concluding remarks}

Studies of private firms are of great interest because of the predominance of this corporate type and their relevance for each country's economy. This study sheds light on a possible benefit associated with Big 4 auditing: reducing the cost of debt. The obtained results, however, do not indicate that the cost of debt falls significantly when a Big 4 firm audits a private firm in the Brazilian sugarcane industry. Hence, lenders in the industry may have other sources of information for solving agency conflicts. The results are robust to a battery of robustness checks and after controlling for characteristics that affect the cost of debt.

The presence of private communication channels, which usually exist between private firms and banks, can reduce part of the information asymmetry problems and ease the information flow between the two parties (Beck et al., 2008; Diamond, 1991). Thus, in a further robustness check, we verify that direct communication via private channels can be more important for banks and credit unions than financial reports audited by a Big 4 firm.

Therefore, our findings do not provide support of the existence of a cost of debt reduction for firms audited by a Big 4 firm in comparison to those audited by a non-Big 4 firm. This result suggests that banks can overcome problems related to the low quality of financial statements via informal communication channels together with other sources of information, even if a Big 4 auditor does not audit a firm (Bharath et al., 2008; Kim et al., 2011).

Despite the methodological procedures and the care taken in the analyses of the result, this study is subject to limitations. First, the sample is restricted. Moreover, the difficult access to the financial reports of some of the organizations in this study limited the number of observations, especially regarding the information on the existence of an external audit, and, if so, the audit company conducting it. In the same way, due to data limitation, we did not have access to certain control variables that have been identified as significant factors in determining the interest rate, such as the presence of collateral, the terms of the loan and the length of the banking relationship.

Second, estimations can be affected by endogeneity problems. Thus, even when using the fixed effects regressions and the Arellano and Bond (1991) GMM estimator, endogeneity is not absent in this study since the relationship between the cost of debt and the audit is bidirectional. In other words, it is worth noting that articles about auditor choice present endogeneity problems, given that the choice of whether to use a Big 4 auditor is not random but is a corporate decision.

\section{Supplementary material}

Supplementary material can be found online at https://doi.org/10.22434/IFAMR2020.0033

Table S1. Correlation matrix and variance inflation factor.

\footnotetext{
${ }^{4}$ Credit unions represent an important part of the Brazilian financial system. The main purpose of credit unions in Brazil is to provide financial services to its members based on collective savings (Abreu et al., 2018).
} 


\section{Acknowledgement}

We thank the CNPq by their financial support and 2018 AAA Annual Meeting for helpful comments.

\section{References}

Abreu, E.S., H. Kimura, L.M. Araújo Neto and Y. Peng. 2018. Efficiency of the Brazilian credit unions: a joint evaluation of economic and social goals. Latin American Business Review 19(2): 107-129. https://doi.org/10.1080/10978526.2018.1479640

Arellano, M. and S. Bond. 1991. Some tests of specification for panel data: Monte Carlo evidence and an application to employment equations. Review of Economic Studies 58(2): 277-297. https://doi. org/10.2307/2297968

Ascioglu, A., S. Hegde and L.B. Mcdermott. 2008. Information asymmetry and investment-cash flow sensitivity. Journal of Banking \& Finance 32(6): 1036-1048. https://doi.org/10.1016/j.jbankfin.2007.09.018

Assaf Neto, A. 2014. Finanças corporativas e valor, $7^{\text {th }}$ edition. Atlas, São Paulo, Brazil.

Ball, R. and L. Shivakumar. 2005. Earnings quality in UK private firms: comparative loss recognition timeliness. Journal of Accounting and Economics 39(1): 83-128. https://doi.org/10.1086/296668

Beck, T., A. Demirguc-Kunt and V. Maksimovic. 2008. Financing patterns around the world: are small firms different? Journal of Financial Economics 89(3): 467-487. https://doi.org/10.1016/j.jfineco.2007.10.005

Becker, C.L., M.L. Defond, J. Jiambalvo and K.R. Subramanyam. 1998. The effect of audit quality on earnings management. Contemporary Accounting Research 15(1): 1-24. https://doi. org/10.1111/j.1911-3846.1998.tb00547.x

Berger, A. and G.F. Udell. 1995. Relationship lending and lines of credit in small firm finance. The Journal of Business 68(3): 351-381. https://doi.org/10.1086/296668

Bharath, S.T., J. Sunder and S. Sunder. 2008. Accounting quality and debt contracting. The Accounting Review 83(1): 1-28. https://doi.org/10.2308/accr.2008.83.1.1

Bigus, J. and C. Hillebrand. 2017. Bank relationships and private firms' financial reporting quality. European Accounting Review 26(2): 379-409. https://doi.org/10.1080/09638180.2016.1152906

Bushman, R.M. and A.J. Smith. 2001. Financial accounting information and corporate governance. Journal of Accounting and Economics 32(1-3): 237-333. https://doi.org/10.1016/S0165-4101(01)00027-1

Cassar, G. 2011. Discussion of the value of financial statement verification in debt financing: evidence from private U.S. firms. Journal of Accounting Research 49(2): 507-528. https://doi.org/10.1111/j.1475679X.2011.00412.x

Chaney, K., D.C. Jeter and L. Shivakumar. 2004. Self-selection of auditors and audit pricing in private firms. The Accounting Review 79(1): 51-72. https://doi.org/10.2308/accr.2004.79.1.51

Choi, J.H. and T.J. Wong. 2007. Auditors' governance functions and legal environments: an international investigation. Contemporary Accounting Research 24(1): 13-46. https://doi.org/10.1506/X4781075-4PW5-1501

Clatworthy, M.A., G.H. Makepeace and M.J. Peel. 2009. Selection bias and the big four premium: new evidence using Heckman and matching models. Accounting and Business Research 39(2): 139-166. https://doi.org/10.1080/00014788.2009.9663354

Crisóstomo, V.L., F.J. Iturriaga and E. González. 2013. Financial constraints for investment in Brazil. International Journal of Managerial Finance 10(1): 73-92.

Daly, A. and H.A. Skaife. 2016. Accounting for biological assets and the cost of debt. Journal of International Accounting Research 15(2): 31-47. https://doi.org/10.2308/jiar-51335

DeAngelo, L.E. 1981. Auditor size and audit quality. Journal of Accounting and Economics 3(3): 183-199. https://doi.org/10.1016/0165-4101(81)90002-1

Defond, M. and J. Zhang. 2014. A review of archival auditing research. Journal of Accounting and Economics 58(2-3): 275-326. https://doi.org/10.1016/j.jacceco.2014.09.002

Diamond, D.W. 1989. Reputation acquisition in debt markets. Journal of Political Economy 97(4): 828-862. https://doi.org/10.1086/261630 
Diamond, D.W. 1991. Monitoring and reputation: the choice between bank loans and directly placed debt. Journal of Political Economy 99(4): 689-721. https://doi.org/10.1086/261775

Fortin, S. and J.A. Pittman. 2007. The role of auditor choice in debt pricing in private firms. Contemporary Accounting Research 24(3): 859-896. https://doi.org/10.1506/car.24.3.8

Hope, O.K. and D. Vyas. 2017. Private company finance and financial reporting. Accounting and Business Research 47(5): 506-537. https://doi.org/10.1080/00014788.2017.1303963

Hope, O.K., J.C. Langli and W.B. Thomas. 2012. Agency conflicts and auditing in private firms. Accounting, Organizations and Society 37(7): 500-517. https://doi.org/10.1016/j.aos.2012.06.002

Hope, O.K., W.B. Thomas and D. Vyas. 2013. Financial reporting quality of U.S. private and public firms. The Accounting Review 88(5): 1715-1742. https://doi.org/10.2308/accr-50494

Huguet, D. and J.L. Gandía. 2014. Cost of debt capital and audit in Spanish SMEs. Spanish Journal of Finance and Accounting 43(3): 266-289. https://doi.org/10.1080/02102412.2014.942154

Jensen, M.C. and W.H. Meckling. 1976. Theory of the firm: managerial behavior, agency costs and ownership structure. Journal of Financial Economics 3(4): 305-360.

Kim, J.B., D.A. Simunic, M.T. Stein and C.H. Yi. 2011. Voluntary audits and the cost of debt capital for privately held firms: Korean evidence. Contemporary Accounting Research 28(2): 585-615. https:// doi.org/10.1111/j.1911-3846.2010.01054.x

Lennox, C., J.R. Francis and Z. Wang. 2012. Selection models in accounting research. The Accounting Review 87(2): 589-616. https://doi.org/10.2308/accr-10195

Lyandres, E. 2007. Costly external financing, investment timing, and investment-cash flow sensitivity. Journal of Corporate Finance 13(5): 959-980. https://doi.org/10.1016/j.jcorpfin.2007.07.001

Manoel, A.A.S., J.P.A. Eça and M.B.C. Moraes. 2016. Custo do Capital Próprio em Empresas Brasileiras do Setor Sucroenergético: um estudo considerando a adoção das Normas Internacionais de Contabilidade. Revista Universo Contábil 12(2): 117-137. doi:10.4270/ruc.2018214

Manoel, A.A.S., M.B.C. Moraes, D.F.L. Santos and M.F. Neves. 2017. Determinants of corporate cash holdings in times of crisis: insights from Brazilian sugarcane industry private firms. International Food and Agribusiness Management Review 21(2): 201-218. https://doi.org/10.22434/IFAMR2017.0062

Manoel, A.A.S., M.B.C. Moraes, J.P.A. Eça and A.J. Rezende. 2018. The IFRS adoption and the cost of debt: a study with private firms from the Brazilian sugarcane industry. Custos e @gronegócio 14(4): 167-193.

Mansi, S.A., W.F. Maxwell and D. Miller. 2004. Does auditor quality and tenure matter to investors? Evidence from the bond market. Journal of Accounting Research 42(4): 755-793. https://doi.org/10.1111/j.1475679X.2004.00156.X

Minnis, M. 2011. The value of financial statement verification in debt financing: evidence from private U.S. firms. Journal of Accounting Research 49(2): 457-506. https://doi.org/10.1111/j.1475679X.2011.00411.x

Petersen, M.A. and R.G. Rajan. 1994. The benefits of lending relationships: evidence from small business data. The Journal of Finance 49(1): 3-37. https://doi.org/10.1111/j.1540-6261.1994.tb04418.x

Piot, C. and F. Missonier-Piera. 2007. Corporate governance reform and the cost of debt financing of listed French companies. Working Paper. Available at SSRN: https://papers.ssrn.com/sol3/papers. cfm?abstract id $=960681$

Pittman, J.A. and S. Fortin. 2004. Auditor choice and the cost of debt capital for newly public firms. Journal of Accounting and Economics 37(1): 113-136. https://doi.org/10.1016/j.jacceco.2003.06.005

Rodríguez, M.C. and S.S. Alegría. 2012. The value of audit quality in public and private companies: evidence from Spain. Journal of Management \& Governance 16(4): 683-706. https://doi.org/10.1007/s10997011-9183-4

União da Indústria de Cana-de-Açúcar (UNICA). Setor Sucroenergético no Brasil uma visão para 2030. UNICA, Brasília, Brazil. Available at: https://www.novacana.com/pdf/UNICA-CEISE___Setor_ Sucroenergetico_no_Brasil_Uma_Visao_para_2030_16022017100211.pdf 